\title{
Do not feed the predators
}

\author{
P. de Jager ${ }^{a \star}$, F. de Kock ${ }^{b}$ and P. van der Spuyc
}

\author{
aDepartment of Finance and Tax, University of Cape Town, South Africa \\ ${ }^{b}$ School of Management Studies, University of Cape Town, South Africa \\ ${ }^{\mathrm{c} S}$ School of Accountancy, Stellenbosch University, South Africa
}

*To whom all correspondence should be addressed

phillip.dejager@uct.ac.za

\begin{abstract}
This study investigates the prevalence and characteristics of papers published in popular predatory journals by South African academics in economic and management sciences. Our aim is to raise awareness and to deepen understanding of the predatory publishing phenomenon. We collected 728 recent (2013 to mid-2016) articles with South African authors in five popular in the field journals classified as 'potential, possible, or probable predatory' according to Beall's list. Our data shows that publishing in these predatory journals is widespread across authors and universities. However, the data also shows that most of the authors only published once in these journals, suggesting that they perhaps mistakenly perceived the journals as being legitimate research outlets. We found evidence of low-quality publishing by the journals in our data, consistent with deficient peer review and copy editing processes. Thus, low-quality publishing was evident from spelling and grammar mistakes in the titles of articles, publishing the same paper twice in the same journal, so-called 'salami slicing', and the publishing of an article already published in another journal.
\end{abstract}

If a large number of South African academics publish papers in predatory journals, then those journals become legitimised locally, leading to other South African academics also publishing in them. This can create a dangerous downward spiral in research quality.

\section{Introduction}

The aim of this study is to report on the prevalence, during recent years, of publications in popular predatory journals by South African academics in economic and management sciences. In doing so, we wish to raise awareness of predatory publishing in this local context and deepen understanding of the phenomenon. Our data shows that the problem of publications in predatory journals is serious. However, the data suggests that most of the authors may have been misled by the journals. In a twist of irony, that emphasises how aggressively predatory publishers are pursuing South African authors, an initial version of our paper was hijacked by a predatory journal. ${ }^{1}$ A further contribution of our study is to provide detailed evidence of low-quality publishing by the five journals we covered.

The rise of the open access (OA) movement has led to an increase in predatory publishing (Berger \& Cirasella, 2015:132). The term 'predatory publishing' refers to the publishing of academic papers without the necessary controls, such as appropriate peer review and professional copy editing, to ensure high-quality research. Predatory publishers are primarily profit seeking and are not campaigning for the dissemination of high-quality research

\footnotetext{
${ }^{1}$ A spoof website (www.sajbm.com) for the South African Journal of Business Management was used to obtain a first version of the paper. That version was then published by Zeitschrift fur Psychologie without any peer
}

findings and the furtherance of knowledge (Department of Higher Education \& Training (DHET), 2014:39). The problem is particularly acute when incentives overlap: for example, profit-seeking journals charge authors to publish their papers and thus want to publish as many papers as possible; meanwhile, authors are incentivised to focus on the quantity of research output rather than on its quality. The South African system of 'accredited journals' encourages a focus on volume of research output (Harley, Huysamen, Hlungwani \& Douglas, 2016:114; Mouton \& Valentine, 2017:86) which makes South African authors vulnerable to the predators.

Publications in predatory journals have profound adverse consequences, not only for individual researchers, but also for a national academic research system. Predatory publishers tempt emerging researchers to submit their work to journals where not only rapid publication, but also a high probability of success, are almost guaranteed. In the short term, scarce resources such as time and money are wasted on research that does not enjoy scientific credibility. Over the longer term, these researchers (who might later become research supervisors, or reviewers for journals, or serve as members of evaluation committees for the National Research Foundation (NRF)) may eventually become adapted to low research

review or transfer of copyright from the authors. The actual Zeitschrift für Psychologie is a well-respected journal in psychology (note how the spelling of the journal names differ in terms of the dots on "fur"). 
standards and propagate those standards. The propagation might be due to a lack of knowledge or, more likely, due to their sunk investment of time and effort in those predatory journals that motivates an upkeep of the journals as legitimate research outlets. If left unchecked, publications in predatory journals may eventually erode the credibility and reputation of South African research and research institutions. There is also an inherent opportunity cost to consider; publications in predatory journals effectively displace scarce research resources (such as research funding in the form of government subsidies) that may have benefited other research published in legitimate outlets.

Against this background, we investigate the claim that the publication of articles in predatory journals by South African academics in economic and management sciences is on the increase, despite warnings against the practice (DHET, 2014:40). We venture that this may be due to local researchers collectively legitimising these journals. To this end, we have compiled and analysed a dataset of 728 articles with South African affiliated authors, published in the five most popular predatory journals in economic and management sciences for the period 2013 to mid-2016. We identified journals as predatory by their inclusion on the nowwithdrawn Beall's list (Beall, 2016), as done in a number of other studies (Bagues, Sylos-Labini \& Zionovyeva, 2016; Mouton \& Valentine, 2017; Pyne, 2017; Wallace \& Perri, 2016). Beall is widely acknowledged as a leading authority on predatory publishers (Berger \& Cirasella, 2015:132; Butler, 2013). Cabell's International launched a substitute for Beall's list on 15 June 2017 (Silver, 2017) that is hoped will fill the gap left by the withdrawal of Beall's list.

Our study has practical importance for the academic landscape in South Africa. First, although predatory publishing is a global phenomenon, authors from developing countries such as South Africa are particularly susceptible to it (Bohannon, 2013:65; Butler, 2013:434). For example, South African affiliated authors published extensively in the predatory Mediterranean Journal of Social Sciences (Thomas, 2015; Aitchison, 2015) that was specifically highlighted by the DHET; this finding indicates that South Africa is probably one of the problem regions where the publication of papers by local authors in predatory OA journals is rife (Shen \& Björk, 2015). Second, we present evidence that the peer review and copy editing processes in the five journals that we sampled are not of a high standard. We hope that our evidence will convince South African academics to avoid these (and similar) journals.

Ours is not the only current study that investigates the prevalence of publications in predatory journals using Beall's list. Pyne (2017) found "that the majority of faculty with research responsibilities at a small Canadian business school have publications in predatory journals." In Italy, Bagues, Sylos-Labini and Zionovyeva (2016) found that about 5\% of researchers have such publications. In economics, Wallace and Perri (2016) found that 124 authors registered on the Research Papers in Economics archives (RePEc) were publishing in predatory journals in 2015. In South Africa, Mouton and Valentine (2017) investigated the extent of publishing in predatory journals across all academic disciplines for the period 2005 to 2014 . They made use of the publication data that South African universities annually submit to the DHET. Our study differentiates itself from the Mouton and Valentine (2017) study that is, admittedly, much more extensive. First, we go into more detail in our study. Details such as the identities of editorial board members are important to understand the journal legitimising process that we identify. Detailed work such as scrutinizing carefully the titles of the articles published in the journals is useful to obtain evidence of low-quality publishing. Second, we use a different data source that is more up to date: the predatory journals' archives.

The paper is structured as follows. A review of the literature explains the predatory publishing concept and the importance of Beall's list. The review is then extended to cover the international and the South African research systems' response to the predatory publishing phenomenon. The data and method section explain how the data was gathered and analysed. This provides a background to the findings and discussion presented afterwards. The conclusion highlights the main contributions of the study and indicates opportunities for further investigation.

\section{Literature review}

\section{Predatory publishers/journals}

The growth of predatory publishing is associated with the emergence of the OA movement. Previously, under the 'user pays' principle, the publisher was incentivised to publish high-quality research or else no reader would pay for access. This changed with the advent of the internet and the concurrent social pressure for open access to research where the business model is now that the author pays article processing charges ${ }^{2}$ and the reader has free access. Berger and Cirasella (2015:132), writing as supporters of the OA movement, admit that "No matter how strong our urge to support and defend OA, librarians cannot deny the profusion of predators in the OA arena..." This perhaps explains why Jeffrey Beall, who coined the term 'predatory publishers', includes in his definition an explicit reference to OA publishers.

Although OA is one of the indicators of a potential predatory publication, a number of other diagnostic criteria are indicative of the predatory status of a journal. The so-called Beall's list (Beall, 2016) is acknowledged as the highest profile watchdog resource to identify predatory publishers (Berger \& Cirasella, 2015:132; Butler, 2013). Naturally Beall's list attracts criticism; these vary from arguments that Beall's list may be prejudiced against OA in general, placing

\footnotetext{
${ }^{2}$ Not all open access journals rely on article processing charges. Solomon and Björk (2012) found that $26 \%$ of journals listed in the Directory of Open Access Journals (DOAJ) ask article processing charges.
} 
himself in "a position of prosecutor, judge and jury", or being meaningless altogether (Fiebert, 2014). Others (e.g., Aitchison, 2015) support Beall's list as a first, if imperfect, step towards preventing the proliferation of predatory journals. If left unchecked, the proliferation of predatory journals and their assimilation into mainstream academic publication can potentially lead to a breakdown of the academic research system, as the promotion of academics in such a system is potentially no longer based on merit.

\section{Research systems' response}

Internationally, research systems in different countries have shown varied responses to the emergence of predatory publishing. In Belgium, in response to questions about the occurrence of predatory journals on the journal list of the Vlaams Academisch Bibliografisch Bestand voor de Sociale en Humane Wetenschappen, the bureau of the Authoritative Panel authorised an investigation (Rahman, Guns \& Engels, 2015), where investigators were tasked with identifying instances of predatory journals according to Beall. Their report of February 2014 included a decision not to give accreditation to articles published with predatory publishers (Rahman, Guns \& Engels, 2015:2). Similarly, the Australian Business Deans Council (ABDC) conducted an interim review in 2016 of the quality of their journal list with four narrowly defined objectives; one of these was to remove predatory journals from the list (ABDC, 2016). It is clear that the phenomenon of predatory publishing is receiving international attention.

In South Africa, the DHET (2014:39) in their "Report on the evaluation of the 2013 universities' research outputs" argues that an unintended consequence of the South African research subsidy system was an increased focus on quantity rather than quality of research. In addition, the report highlights so-called 'salami publishing': "where authors publish more than one paper from work that should have resulted in only one paper" (DHET, 2014:39). In terms of predatory publishing, the report argues, "Authors/researchers should not submit their journal output/s for subsidy claims if they have published in a journal that does not adhere to the research output policy, as that constitutes a fraudulent activity. Institutions should put mechanisms in place to ensure that such practices do not occur" (DHET, 2014:39).

The national research policy has also found its way into inhouse institutional research policy at university level. For example, the research office of the University of Cape Town has indicated in an email communication to the authors the intention that articles in journals listed on Beall's list will not be forwarded to the DHET for subsidy purposes in 2016. On its website, Stellenbosch University warns its research community of the existence and implications of Beall's list and provides direct links to appropriate websites for further education regarding predatory journals (Stellenbosch University, 2015). The NRF, in their 2016 rating review process, specifically instructed reviewers to be on the lookout for and report on publications in predatory journals (NRF, 2016).
The South African research system's response shows that momentum is building towards a clampdown on publications in predatory journals.

\section{The present study}

Despite the inherent dangers of predatory publication for the research community in South Africa, academics may not have responded adequately to repeated calls to pursue appropriate research outlets for their work. Against the background summarised above, our study investigates the prevalence of predatory publication by economic and management sciences academics in South Africa during the period 2013 to mid2016.

\section{Data and method}

\section{Identifying popular predatory journals}

We first had to identify predatory journals that were popular as publication outlets for South African academics in economic and management sciences. To this end, we scanned the 2014 faculty research reports of various South African research universities to identify any publications in journals that featured on Beall's list (the July 2016 version). In addition, the websites of various economic and management sciences departments were also scanned to identify any publications in predatory journals. Five journals were identified as popular, based on the number of occurrences. We were able to cross-reference our choice of predatory journals to the top predatory journals published in, by economic and management sciences academics, in the database of the Centre for Research on Evaluation, Science and Technology (CREST) at Stellenbosch University. CREST collects all the annual submissions of journal articles to the DHET from South African universities (the data is currently up to 2014).

\section{Classifying all articles published in the five most popular predatory journals (2013 - mid-2016)}

After identifying the five most popular predatory journals in the field of economic and management sciences, we visited the archives of those journals and captured data about the characteristics of each published article; for example, the publication year, title, author name/s and their affiliation/s). In order to augment the article data further, we sought current information (on the internet, for example, department websites, professional social media, etc.) about the author's departmental affiliation and scholarly rank. We retained an article only if it included at least one author affiliated to a South African university. We decided to include only those studies published from 2013 onwards, since 'predatory journals' were first addressed in the DHET's report on research output for 2013 (DHET, 2014:39).

\section{Delimitations and limitations}

We are delimiting our data collection to the five most popular predatory journals for the period 2013 to mid-2016. By 
implication, we did not include every article published by economic and management sciences academics in a predatory journal for the period. It is to be expected that academics in economic and management sciences, affiliated to South African universities, have published in these five journals before 2013; however, our approach will not identify those instances.

Our approach is also critically dependant on Beall's list. We acknowledge that this list is dynamic and was removed from the internet in January 2017. Thus, some of the journals we included in our study may have been removed from Beall's list at the time of going to press.
We will augment Beall's classification of the journals with information from authoritative sources and evidence obtained during the course of our investigation.

\section{Results}

\section{Popular predatory journals}

Table 1, below, gives details of the five predatory journals identified through our explorative process.

\section{Table 1: Details of predatory journals identified as being popular with South African authors}

\begin{tabular}{|c|c|c|c|c|c|c|c|c|c|}
\hline \multirow[b]{2}{*}{ Journal } & \multirow[b]{2}{*}{ Publisher } & \multirow[b]{2}{*}{$\begin{array}{l}\text { Payment by } \\
\text { author }\end{array}$} & \multicolumn{3}{|c|}{ SUBSIDY EARNING? } & \multicolumn{4}{|c|}{ QUALITY INDICATORS } \\
\hline & & & $\begin{array}{l}\text { Web of } \\
\text { science }\end{array}$ & IBSS & Scopus & $\begin{array}{c}\text { DOAJ } \\
\text { whitelist } \\
\text { (Jan 2017) } \\
\end{array}$ & $\begin{array}{c}\text { DOAJ green } \\
\text { tick (Jan } \\
2017) \\
\end{array}$ & $\begin{array}{l}\mathrm{ABDC} \\
\text { rating }\end{array}$ & $\begin{array}{l}\text { ABS } \\
\text { (UK) } \\
\text { rating } \\
\end{array}$ \\
\hline $\begin{array}{l}\text { Corporate } \\
\text { Ownership \& } \\
\text { Control }\end{array}$ & $\begin{array}{l}\text { Virtus } \\
\text { InterPress, } \\
\text { Ukraine } \\
\end{array}$ & $\begin{array}{l}440 \text { Euros }+ \\
\text { extra for } \\
\text { expediting }\end{array}$ & No & $\begin{array}{c}\text { No } \\
\text { (previously } \\
\text { listed) }\end{array}$ & $\begin{array}{c}\text { Previously } \\
\text { listed but } \\
\text { removed in } \\
2017 \\
\end{array}$ & NA & NA & $\begin{array}{l}\text { Previously } \\
\text { rated B } \\
\text { but } \\
\text { removed } \\
\text { in } 2016 \\
\end{array}$ & 1 \\
\hline $\begin{array}{l}\text { International } \\
\text { Business \& } \\
\text { Economics } \\
\text { Research Journal }\end{array}$ & $\begin{array}{l}\text { The Clute } \\
\text { Institute, } \\
\text { United States }\end{array}$ & $\begin{array}{l}400-1600 \\
\text { dollars based } \\
\text { on word count }\end{array}$ & No & Yes & No & Yes & No & Not rated & $\begin{array}{c}\text { Not } \\
\text { rated }\end{array}$ \\
\hline $\begin{array}{l}\text { Journal of } \\
\text { Applied Business } \\
\text { Research }\end{array}$ & $\begin{array}{l}\text { The Clute } \\
\text { Institute, } \\
\text { United States }\end{array}$ & $\begin{array}{l}400-1600 \\
\text { dollars based } \\
\text { on word count }\end{array}$ & No & Yes & Yes & No & No & Not rated & $\begin{array}{c}\text { Not } \\
\text { rated }\end{array}$ \\
\hline $\begin{array}{l}\text { African Journal } \\
\text { of Business } \\
\text { Management }\end{array}$ & $\begin{array}{l}\text { Academic } \\
\text { Journals, } \\
\text { Nigeria } \\
\end{array}$ & 550 dollars & No & No & No & No & No & Not rated & $\begin{array}{c}\text { Not } \\
\text { rated }\end{array}$ \\
\hline
\end{tabular}

Information on payment by author was obtained from the journal websites during October 2016. In South Africa the DHET subsidises academic research output if an article is published in a journal on an accredited journal list: a journal on Thomson Reuters' Web of Science; a journal indexed by the International Bibliography of the Social Sciences (IBSS); a journal listed on the Norwegian Register for Scientific Journals (none of the journals above appear on this list which is thus not indicated); a journal indexed by Scopus; or a journal listed on the DHET's local list (none of the journals above appear on this list which is thus not indicated). The Directory of Open Access Journals (DOAJ) is a community-curated list of OA journals that subscribe to minimum standards of publishing quality. The DOAJ green tick is displayed against all journals that were accepted onto DOAJ after March 2014 when the DOAJ launched its new criteria for journals to be accepted. The new criteria require a higher level of compliance to best practices and publishing standards. The ABDC maintains a journal quality list and gives quality ratings to journals. Similarly, in the United Kingdom, the Chartered Association of Business Schools (ABS) maintains an academic journal guide.

Next, we address in turn the characteristics of each of the selected journals and make further supplementary notes.

\section{Corporate Ownership \& Control}

The journal Corporate Ownership \& Control is popular with South African authors. ${ }^{3}$ It charges authors an acceptance fee of 440 Euros (obtained from journal's website on 22 October 2016) with a further payment possible to expedite the publication of a paper. However, the journal is not OA as readers still have to pay for access. It will therefore not feature on the whitelist of OA journals maintained by the Directory

${ }^{3}$ The publisher was on Beall's list during the period of our study (2013 to mid-2016). However, on 4 August 2016 the publisher was removed from Beall's list of predatory publishers after a second successful appeal. Issues raised about the journal (and the publisher) by authoritative sources and the of Open Access Journals (DOAJ). Articles published in the journal for 2016 should normally be subsidy earning as the journal was on the Scopus list. The journal has been removed from Scopus from 2017 onwards. The name of a South African academic is listed on the journal's website (on 22 October 2016) as serving on the editorial board of the journal. ${ }^{4}$ This serves to legitimise the journal in the South African context. Additional local legitimacy is obtained from the listing of fifty South African academics as reviewers for the publisher.

In terms of quality, the journal used to be rated as $\mathrm{B}$ by the $\mathrm{ABDC}$, with $\mathrm{A}^{*}$ being the best category and $\mathrm{C}$ the worst. The

evidence obtained during our investigation support the initial classification by Beall.

${ }^{4}$ This editorial board membership is not listed on the linked curriculum vitae of the academic in question. It is common for predatory journals to list academics, without their permission, as serving on the editorial board. 
ABDC removed their accreditation of the journal after an interim 2016 review with the following argument: "Although Virtus Interpress has been removed from Beall's list of predatory publishers (as of 4 August), consultation with wellrespected senior representatives in the accounting field and a review of recently published papers do not provide the confidence that the review process is of an acceptable standard." In the United Kingdom (UK) the journal received the lowest rating available by the Chartered Association of Business Schools (ABS) in 2015. According to the Serials Union Catalogue for the UK research community (SUNCAT) only one library in the UK subscribes to the journal. This indicates low quality as nobody is willing to pay for access. According to Scopus, the 2015 citations per document was a low 0.12 , again indicative of a low-quality publication.

During our web searches related to the publisher Virtus InterPress, we came across documents on their website titled: "Highlighting the corporate governance research communities: A case of the University of South Africa" (Virtus InterPress, 2012a) and "Highlighting the corporate governance research communities: A case of Stellenbosch University" (Virtus InterPress, 2012b). The publisher celebrates the "cooperation with the journal" by academics from the two universities in the two documents. In the conclusions of both documents, using exactly the same words, the publisher called for other researchers to follow the example set: "We are open to all ways of cooperation with experts and institutions from different corners of the world to share valuable experience in solving problems in the field of corporate governance, in both developed and developing countries" (Virtus InterPress, 2012a; Virtus InterPress, 2012b). This looks like a legitimisation process that targets South Africa. The Virtus InterPress website also has a page titled "The Loyal Authors' Club" that prominently lists three Stellenbosch University professors as loyal authors.

\section{Risk governance and control: Financial markets \& institutions}

The journal Risk Governance and Control: Financial Markets \& Institutions is also popular with South African authors. It charges authors an acceptance fee of 360 Euros (obtained from journal's website on 22 October 2016) with a further payment possible to expedite the publication of a paper. However, the journal is not OA as readers still have to pay for access. It will thus not feature on the whitelist of OA journals as maintained by the DOAJ. Articles published in the journal for 2016 should normally be subsidy earning as the journal was on the Scopus list. The journal has been removed from Scopus from 2017 onwards. Some local legitimacy is obtained from the listing of fifty South African academics as reviewers for the publisher.

In terms of quality, the journal is not rated by the ABDC or in the UK by the ABS. The Flemish Academic Bibliography for the Social Sciences and Humanities (VABB-SHW) classifies the journal as non peer-reviewed (Sile, Guns \& Engels, 2017:20). According to SUNCAT, only two libraries in the UK subscribe to the journal. This indicates low quality as nobody is willing to pay for access. According to Scopus the 2015 citations per document was a low 0.09, again indicative of a low-quality publication.

\section{International Business \& Economics Research Journal}

The International Business \& Economics Research Journal is also popular with South African authors. It charges a submission fee of 75 dollars and an OA fee of between 400 and 1600 dollars (fees were confirmed on the journal's website on 22 October 2016), depending on word count, upon acceptance of a paper. Articles published in the journal for 2016 should normally be subsidy earning as the journal is on the IBSS list. The names of thirteen South African academics are listed on the journal's website (on 22 October 2016) as editors of the journal, and serve to legitimise the journal in the South African context. Additional local legitimacy is obtained from the listing of a further thirteen South African academics as reviewers for the journal.

However, the journal has limited signs of quality. It does appear on the DOAJ list of "high quality, open access, peerreviewed journals." However, it does not have a green tick from the DOAJ, signifying that it does not meet the "new criteria require a higher level of compliance to best practices and publishing standards." It is not rated by the ABDC nor by the ABS in the UK. Scopus citation data for 2015 is not available as the journal is not indexed by Scopus.

\section{Journal of Applied Business Research}

The Journal of Applied Business Research is also popular with South African authors. It charges a submission fee of 75 dollars and an OA fee of between 400 and 1600 dollars depending on word count (fees were confirmed on the journal's website on 22 October 2016), upon acceptance of a paper. Articles published in the journal for 2016 should normally be subsidy earning as the journal is on both the IBSS and the Scopus lists. The names of four South African academics are listed as editorial board members on the journal's website (on 22 October 2016), and serve to legitimise the journal in the South African context.

However, the journal has no signs of quality as measured. It does not appear on the DOAJ list. It is not rated by the ABDC or by the ABS in the UK. According to Scopus the 2015 citations per document was 0.29 .

\section{African Journal of Business Management}

The African Journal of Business Management also used to be popular with South African authors. It charges a manuscript handling fee of 550 dollars (fees were confirmed on the journal's website on 22 October 2016) for accepted papers. Articles published in the journal have not been subsidy earning since 2012 when the journal was taken off the Thomson Reuters Master Journal List because of dubious publication practices (Beall, 2012). In 2016, the journal was also removed from the DOAJ's whitelist. However, eight 
South African academics are still listed as editors on the website (22 October 2016). One South African academic is indicated as serving on the editorial board.

The journal has no signs of quality as measured. It does not appear on the DOAJ list, neither is it rated by the ABDC nor by the ABS in the UK. Scopus citation data for 2015 is not available as the journal is not indexed by Scopus.

These five international journals have a number of South African academics involved in the editorial operations of the journal. The journals gain local legitimacy as publication outlets when other South African academics see the names of their colleagues involved with the journals.

\section{Number of South African articles in predatory journals}

Table 2 below shows the total number of articles published in the five journals by South African authors for the period 2013 to mid-2016.

Table 2: Total number of articles published per year in each journal and the number of articles in each journal per year with an author affiliated to a South African university

\begin{tabular}{|c|c|c|c|c|c|c|c|c|c|c|c|c|}
\hline & \multicolumn{3}{|c|}{2013} & \multicolumn{3}{|c|}{2014} & \multicolumn{3}{|c|}{2015} & \multicolumn{3}{|c|}{2016} \\
\hline Journal & $\begin{array}{l}\text { Total } \\
\text { papers }\end{array}$ & $\begin{array}{l}\text { SA } \\
\text { papers }\end{array}$ & $\%$ & $\begin{array}{l}\text { Total } \\
\text { papers }\end{array}$ & $\begin{array}{l}\text { SA } \\
\text { papers }\end{array}$ & $\%$ & $\begin{array}{l}\text { Total } \\
\text { papers }\end{array}$ & $\begin{array}{l}\text { SA } \\
\text { papers }\end{array}$ & $\%$ & $\begin{array}{l}\text { Total } \\
\text { papers }\end{array}$ & $\begin{array}{l}\text { SA } \\
\text { papers }\end{array}$ & $\%$ \\
\hline Corporate ownership \& control & 170 & 66 & $39 \%$ & 236 & 70 & $30 \%$ & 283 & 94 & $33 \%$ & 68 & 21 & $31 \%$ \\
\hline $\begin{array}{l}\text { Risk Governance and Control: } \\
\text { Financial Markets \& Institutions }\end{array}$ & 34 & 14 & $41 \%$ & 42 & 23 & $55 \%$ & 76 & 48 & $63 \%$ & 39 & 17 & $44 \%$ \\
\hline $\begin{array}{l}\text { International Business \& } \\
\text { Economics Research Journal }\end{array}$ & 135 & 85 & $63 \%$ & 141 & 77 & $55 \%$ & 67 & 48 & $72 \%$ & 18 & 8 & $44 \%$ \\
\hline $\begin{array}{l}\text { Journal of Applied Business } \\
\text { Research }\end{array}$ & 150 & 17 & $11 \%$ & 153 & 27 & $18 \%$ & 168 & 28 & $17 \%$ & 99 & 20 & $20 \%$ \\
\hline $\begin{array}{l}\text { African Journal of Business } \\
\text { Management }\end{array}$ & 432 & 47 & $11 \%$ & 100 & 9 & $9 \%$ & 75 & 8 & $11 \%$ & 28 & 1 & $4 \%$ \\
\hline & 921 & 229 & $25 \%$ & 672 & 206 & $31 \%$ & 669 & 226 & $34 \%$ & 252 & 67 & $27 \%$ \\
\hline
\end{tabular}

Data was sourced from the web repositories of the five journals. Only for the journals Corporate Ownership \& Control and Risk Governance and Control: Financial Markets \& Institutions were author affiliations (mostly) not available on the journals' websites. Affiliations for the articles in those two journals were obtained from searching the internet (primarily university websites and Linkedin).

The number of articles published in these journals during the period under review was a substantial 2514 (an annual average of 144 articles per journal), suggesting a focus on publication quantity rather than quality. Articles with South African affiliated authors make up such a significant portion (728 articles in total with an annual average of 43 articles per journal) of all the articles published in these journals that the international orientation of the journals is in question. It is clear that the removal of the African Journal of Business Management from the Thomson Reuters Web of Science list had a sharp and immediate impact on the journal: from 2013 to 2014 total articles published dropped by $77 \%$ and articles published with at least one South African affiliated author dropped by $81 \%$. Most articles by South African authors are in the journals with the highest level of involvement by South African academics in the editorial function (Corporate Ownership \& Control and the International Business \& Economics Research Journal).

The analysis of the articles published in these journals shows that the problem of publication in predatory journals by South African affiliated academics in economic and management sciences is serious (728 articles over three and a half years is a high number). This can be compared to the Mouton and
Valentine (2017) results of 4246 predatory articles over the ten years to 2014 for all academic disciplines in South Africa. It is important for the South African academic system to understand from which institutions the articles in the predatory journals come.

\section{University affiliations of identified articles}

We used the following approach to allocate, to specific South African universities, those articles identified above as being produced by South African authors. Thus, we weighted each author's contribution by the number of authors of that article and allocated the weighted contribution to a university: for example, an article with two authors results in a 0.5 allocation to the university of each author. When the university affiliation of the first author was unknown (often the case for student publications) then the second author's affiliation was applied to the first author. We limited the total number of authors per article to a maximum of three.

Table 3 ranks universities in terms of the number of articles published in the five journals. ${ }^{5}$ 
Table 3: Number of articles per university

\begin{tabular}{|c|c|c|c|c|c|c|}
\hline UNIVERSITY & $\begin{array}{l}\text { CORPORATE } \\
\text { OWNERSHIP \& } \\
\text { CONTROL }\end{array}$ & $\begin{array}{l}\text { RISK } \\
\text { GOVERNANCE } \\
\text { AND CONTROL: } \\
\text { FINANCIAL } \\
\text { MARKETS AND } \\
\text { INSTITUTIONS } \\
\end{array}$ & $\begin{array}{l}\text { INTERNATIONAL } \\
\text { BUSINESS \& } \\
\text { ECONOMICS } \\
\text { RESEARCH } \\
\text { JOURNAL } \\
\end{array}$ & $\begin{array}{l}\text { JOURNAL OF } \\
\text { APPLIED } \\
\text { BUSINESS } \\
\text { RESEARCH } \\
\end{array}$ & $\begin{array}{l}\text { AFRICAN } \\
\text { JOURNAL OF } \\
\text { BUSINESS } \\
\text { MANAGEMENT } \\
\end{array}$ & TOTAL \\
\hline $\begin{array}{l}\text { University of South } \\
\text { Africa }\end{array}$ & 108.5 & 40.0 & 31.2 & 15.5 & 14.0 & 209.1 \\
\hline North-West University & 15.8 & 5.7 & 46.0 & 18.2 & 3.0 & 88.7 \\
\hline Stellenbosch University & 16.0 & 17.0 & 16.0 & 4.0 & 4.0 & 57.0 \\
\hline $\begin{array}{l}\text { University of KwaZulu- } \\
\text { Natal }\end{array}$ & 23.3 & 3.0 & 6.5 & 4.8 & 3.0 & 40.7 \\
\hline $\begin{array}{l}\text { Durban University of } \\
\text { Technology }\end{array}$ & 14.0 & 6.5 & 15.8 & 2.0 & 0.0 & 38.3 \\
\hline $\begin{array}{l}\text { Vaal University of } \\
\text { Technology }\end{array}$ & 1.7 & 0.0 & 19.5 & 11.7 & 0.0 & 32.8 \\
\hline $\begin{array}{l}\text { University of } \\
\text { Johannesburg }\end{array}$ & 6.2 & 6.8 & 8.5 & 8.0 & 2.0 & 31.5 \\
\hline University of Pretoria & 7.3 & 2.0 & 10.0 & 4.3 & 2.3 & 26.0 \\
\hline University of Cape Town & 6.0 & 2.3 & 8.0 & 5.7 & 3.0 & 25.0 \\
\hline $\begin{array}{l}\text { Nelson Mandela } \\
\text { Metropolitan University }\end{array}$ & 0.0 & 0.0 & 18.3 & 3.0 & 3.3 & 24.7 \\
\hline University of Limpopo & 16.0 & 3.0 & 0.0 & 0.0 & 0.0 & 19.0 \\
\hline University of Fort Hare & 1.0 & 0.7 & 8.7 & 0.7 & 6.3 & 17.3 \\
\hline $\begin{array}{l}\text { Cape Peninsula } \\
\text { University of Technology }\end{array}$ & 8.8 & 2.0 & 0.5 & 0.5 & 3.0 & 14.8 \\
\hline $\begin{array}{l}\text { Tshwane University of } \\
\text { Technology }\end{array}$ & 5.7 & 3.8 & 1.0 & 0.0 & 3.7 & 14.2 \\
\hline $\begin{array}{l}\text { University of the Free } \\
\text { State }\end{array}$ & 5.0 & 2.3 & 3.3 & 1.0 & 1.3 & 13.0 \\
\hline $\begin{array}{l}\text { University of } \\
\text { Witwatersrand }\end{array}$ & 3.0 & 0.3 & 5.0 & 0.5 & 2.5 & 11.3 \\
\hline $\begin{array}{l}\text { University of the Western } \\
\text { Cape }\end{array}$ & 0.0 & 0.0 & 4.3 & 3.5 & 0.0 & 7.8 \\
\hline $\begin{array}{l}\text { Central University of } \\
\text { Technology }\end{array}$ & 0.0 & 0.0 & 2.5 & 3.0 & 0.5 & 6.0 \\
\hline $\begin{array}{l}\text { Mangosuthu University } \\
\text { of Technology }\end{array}$ & 4.0 & 0.0 & 0.0 & 0.0 & 1.0 & 5.0 \\
\hline Monash South Africa & 0.3 & 0.0 & 4.0 & 0.2 & 0.0 & 4.5 \\
\hline University of Venda & 0.3 & 0.3 & 0.0 & 3.0 & 0.0 & 3.7 \\
\hline Milpark South Africa & 0.5 & 0.5 & 0.5 & 0.0 & 1.0 & 2.5 \\
\hline Regent Business School & 0.0 & 0.0 & 0.5 & 0.0 & 2.0 & 2.5 \\
\hline Rhodes University & 0.0 & 0.0 & 0.0 & 0.0 & 2.0 & 2.0 \\
\hline $\begin{array}{l}\text { Regenesys Business } \\
\text { School }\end{array}$ & 0.0 & 0.0 & 0.0 & 0.0 & 1.5 & 1.5 \\
\hline University of Zululand & 1.0 & 0.0 & 0.0 & 0.0 & 0.0 & 1.0 \\
\hline $\begin{array}{l}\text { Management College of } \\
\text { Southern Africa }\end{array}$ & 0.5 & 0.0 & 0.0 & 0.0 & 0.0 & 0.5 \\
\hline & 244.9 & 96.3 & 210.1 & 89.5 & $\begin{array}{l}59.5 \\
\end{array}$ & \\
\hline
\end{tabular}

Data was sourced from the web repositories of the five journals. Only for the journals Corporate Ownership \& Control and Risk Governance and Control: Financial Markets \& Institutions were author affiliations (mostly) not available on the journals' websites. Affiliations for the articles in those two journals were obtained from searching the internet. The total number of authors was limited to three per article for the allocation.

Table 3 indicates that publications in the predatory journals originate from almost all South African universities. However, the problem is more acute in a few universities.

\section{Indicators of low-quality publishing in our dataset}

Our method is critically dependant on Beall's list for the identification of the five most popular predatory journals. We did augment the predatory classification by Beall with relevant information from other sources (such as the ABDC, the DOAJ, Scopus and Mouton \& Valentine (2017)) which also indicated that these journals are suspect. We expect that these predatory journals, because of deficient peer review and copy editing processes, will present evidence of low-quality publishing.
In the journal Corporate Ownership \& Control, spelling mistakes appeared in the titles of articles, as shown, for example, in the following articles: "Time driven activity based butged in strategic decisions; implementation in a manufacturing company" and "CEO resistance: The role of bod dependence/independence and CEO profile." A number of articles were also published twice in different issues of the journal, as demonstrated by the following South African authored articles: "Profit making and moral obligations in an economically disparate world: The challenges facing healthcare corporations" that was published twice, first in volume 10 number 2 and then in volume 11 number 1; "The importance of customer needs and expectations in achieving total quality management: A strategic view for future trends" that was also published twice, first in volume 10 number 2 
and then in volume 10 number 3 and "The exploration of the triple helix concept in terms of entrepreneurial universities and corporate innovation" that was also published twice, first in volume 12 number 1 and then in volume 12 number 2 .

The articles "The sectional title industry in South Africa: Perspectives of accounting and auditing practitioners", "The sectional title industry in South Africa: Perspectives of chairmen of bodies corporate" and "The sectional title industry in South Africa: Perspectives of managing agents" serve perhaps to illustrate the DHET's threat of "salami publishing" (DHET, 2014:39) with the different perspectives not logically combined in one article.

The titles of articles in the journal Risk Governance and Control: Financial Markets \& Institutions frequently omitted the necessary grammatical articles ("a"; "an" and "the"). Language and spelling mistakes also appeared in the titles of the articles, as demonstrated in the following articles: "The risk level of Viet Nam non-banking investment and financial services industry under financial leverage during and after the global crisis 2007-2011" and "Corporate social disclosure by public enterprises: Evidence from a less developing African country". A number of articles were also published twice in different issues of the journal, as demonstrated by the following South African authored articles: "Determinants of IPO survival on the Johannesburg Securities Exchange" that was published twice, first in volume 4 number 3 and then in volume 5 number 1 and "Life insurance, financial development and economic growth in South Africa: An application of the autoregressive distributed lag model" that was published twice, first in volume 4 number 3 and then in volume 5 number 1 .

In the International Business \& Economics Research Journal spelling mistakes appeared in the titles of articles, as shown, for example, in the following South African authored articles: "Present-Day Dillemas and Challenges of the South African Tertiary System" and "Sight: The Last Bastion of the Brick and Morter Retailer To Survive?" The articles "Differential Investment Performance in South Africa Based On Gender" and "Differential Investment Performance in South Africa Based On Gender and Age" serve perhaps to illustrate the DHET threat of "salami publishing" (DHET, 2014:39) with the different perspectives not logically combined in one article.

Spelling mistakes were also observed in the titles of articles in the Journal of Applied Business Research, for example: "Using a large sample analysis of Thai listed firms, we address an important question. Do board diversity and network add value to firms? This article extends the debate on the benefits and costs of board diversity and network and their effect on the broad." In addition, this particular article title reads more like a short abstract than a title. The body of the article itself in no way relates to this title: the work was actually done on Zimbabwean data. The following South African article was seemingly published twice in different issues of the journal: "Customer Retention Strategies for Disintermediated Travel Agents: How to Stop Customers from Migrating to Online Booking Channels", first in volume
32 number 2 and then in volume 32 number 3 . However, the publisher objected that the first version of the article had been withdrawn. The remaining version of the article on their website now claims of the withdrawn article: "However, the paper was withdrawn on the request of the authors and modified to secure reference to the first part of the study that was published in the International Business Review, 14(3), 561-574." The quoted claim is wrong, confirming a deficient copy editing process, as the article was not published in the International Business Review, but rather in the other journal published by this publisher, the International Business \& Economics Research Journal.

In the African Journal of Business Management, an article titled "Inhibiting factors in the strategic financial management decision making process: Evidence from South African SMMEs" was noted as also published in the Mediterranean Journal of Social Sciences; this last journal is the one that the DHET specifically highlighted as low quality and not subsidy earning in 2013. The following article was also published twice in different issues of the journal: "Evaluation of the entrepreneurial success factors of small, micro and medium farming enterprises (SMMEs) in the periurban poor communities of George municipality, Western Cape Province, RSA," first in volume 7 number 25 and then in volume 7 number 30 .

All five journals exhibit strong indicators of low-quality publishing.

\section{Discussion}

The first aim of the present study was to describe the prevalence of predatory publishing in the domain of economic and management sciences in South Africa. To this end, we analysed the frequency of articles published by South African academics in five popular predatory journals. Our results show that publication in predatory journals is widespread amongst South African economic and management sciences academics: we found 728 articles published in only five predatory journals over the three and a half years covered by our study. The level of predatory publication revealed in our study has clear financial implications. For example, using an estimated subsidy amount of R100 000 per article, we estimate that a total amount of R70 million could possibly be allocated to articles in journals that do not meet the quality standards for rigorous academic research. A large amount of foreign exchange would also have left the South African economy to fund the page fees of these articles.

The high number of articles by South African academics is probably the result of local legitimisation of the journals. The predatory journals established local legitimacy, first by being on the South African journal accreditation lists and then, importantly, having a critical mass of South African authors publishing in them. Most of the journals also used South African academics on the editorial board or acting as reviewers to establish local legitimacy. This was especially the case for the International Business \& Economics 
Research Journal where six of the journal's editors were from North-West University. Table 3 illustrates the local legitimacy gained where most of North-West University's predatory publications were in this journal, contrary to other South African universities that favoured the journal Corporate Ownership \& Control. It is unlikely that these academic editors had the capacity to sign off on all 361 articles published in the journal over the period. Therefore, the publisher was probably using the names of the editors and that of the North-West University to establish local legitimacy whilst retaining actual editorial control. The publisher Virtus Interpress also made use of advertising material to legitimise their journal locally amongst South African academics; they brought out special reports on their cooperation with Stellenbosch University and the University of South Africa and on their website they had a "Loyal Authors' Club" where South African academics featured prominently.

Related to the preceding implication that these five journals are actively pursuing South African academics, is the observation from our data that most authors appeared only once. The data shows that of the 710 authors, most (68\%) had their names on only one article in the five journals during the period, $14 \%$ had their names on two articles only and $8 \%$ had their names on three articles. If most South African authors were engaging in maximising behaviour (as many accredited publications as possible in a short time even if the journal is suspect) then we would expect more authors with a high number of publications. The exception in our data related to sixteen authors with their names on eight or more articles. One maximising author even had his name on 42 articles. We interpret the low number of articles for most authors to be consistent with the notion that they mistakenly published in a predatory journal because they perceived the journal as being a legitimate research outlet.

Another aim of the present study was to deepen understanding of the predatory publishing phenomenon. Our data clearly indicates that predatory journals do not meet the minimum quality standards to be expected if peer review and copy editing processes are adequate. However, presenting evidence of low-quality publishing is not enough to make a journal predatory; thus, a low-quality journal is not necessarily a predatory one whilst a predatory journal is usually a low-quality one. These five journals were also shown to be actively pursuing South African academics as evidenced by the high proportion of published papers with South African authors, the marketing materials mentioned above and editorial boards (and reviewer panels) with overrepresented South African academics. The combination of low-quality publishing and active pursuit is what makes these journals predatory.

\section{Limitations and opportunities for further research}

We only sampled articles from the five selected predatory journals for a period of three and a half years. It is unlikely that the sample would have captured all publications in predatory journals by South African economic and management sciences academics. However, because of the local legitimisation effect described above, where local researchers congregate to the same journals, we probably captured most. Similarly, we did not consider articles published in these journals before 2013. South African economic and management sciences academics did publish extensively in these journals before 2013 as demonstrated by the following evidence. Yu, Kasongo and Moses (2016) examined the performance of South African departments of economics for the period 2005 to 2016. As part of their examination they collected the details of publications in accredited local and international peer-reviewed journals for those departments. They agreed to query their data for instances of the five journals identified in this study and found 46 articles (one in 2009, ten in 2010, seven in 2011, sixteen in 2012 and twelve in 2013). This gives an indication that publishing by South African economic and management sciences academics in these five predatory journals is not a recent phenomenon. It has been increasing over time.

A number of opportunities for further research can be identified. In general, the data in this paper supports the argument of McKerlich, Ives and McGreal (2013) that predatory journals are more inclined to publish articles by inexperienced academics. However, the assumption of inexperience can be relaxed for the sixteen authors in our dataset who had their names on eight or more articles and an investigation launched into their motivations. This will contribute towards understanding why not only inexperienced academics publish in predatory journals (Pyne, 2017:138). The local academics who are editors or reviewers of the journals investigated in this study can also be interviewed to understand more.

\section{Conclusion}

The objective of this study was to investigate the prevalence of publications in predatory journals by South African affiliated economic and management sciences academics. At the same time, it was thought that the South African case would add to knowledge about the predatory publishing phenomenon. Five predatory journals that are popular with South African economic and management sciences academics were identified and the articles in the web repositories of those journals were then analysed for articles with at least one South African affiliated author (2013 to mid2016). A dataset of 728 articles was thus compiled.

Publishing in these predatory journals is a serious and widespread problem in South Africa. We also found evidence of low-quality publishing that reinforced Beall's classification of these journals as predatory. These journals have been legitimised in the South African system by a combination of the subsidy system in South Africa, the inclusion of South African academics on editorial panels and reviewer lists, advertising material and a large volume of South African authored articles in those journals. 
Highlighting the fact that these journals are of low quality and predatory will not immediately solve the problem. Authors might simply migrate away from these specific journals to other predatory or easy-to-access journals. Over the longer term, the better solution will be to change incentives. Although not much can be done about the incentives for profit-seeking journals, change is possible for author incentives. The future South African academic system should reward quality of research more than quantity of research; first in the research subsidy system but also in the performance appraisal system. A step in that direction is the NRF moving against predatory publications in their 2016 rating review.

The intention of this study was not to 'name-and-shame' authors and institutions. We hope to see authors, their line managers, promotion committees, research offices, and funding bodies applying, increasingly, the required level of scrutiny of potential outlets for their research. To this end, we provide a journal-choice flowchart (in the Appendix) that is customised for the South African academic research system and that focuses on defining characteristics of predatory journals that emerged from this study.

\section{References}

Aitchison, J. 2015. Unscrupulous academics buy into "university 419 scam". Mail \& Guardian, 11 December 2015. [online] URL:http://mg.co.za/article/2015-12-10-unscrupulous-academicsbuy-into-university-419-scam\#.V-JXA1nRUO0.email.

Australian Business Deans Council. 2016. ABDC 2016 interim journal review. [online] URL:http://www.abdc.edu.au/pages/2016review.html.

Bagues, M., Sylos-Labini, M. \& Zionovyeva, N. 2016. A walk on the wild side: an investigation into the quantity and quality of 'predatory' publications in Italian academia. [online] URL: http://www.manuelbagues.com/Walk\%20on\%20the\%20wild\%20$\% 20$ bagues, \%20sylos-labini\%20y\%20zinoveyva.pdf.

Beall, J. 2012. The Continuing Story of the African Journal of Business Management. [online] URL: https://scholarlyoa.com/2012/01/15/ the-continuing-story-of-theafrican-journal-of-business-management/.

Beall, J. 2016. Beall's list. [online] URL:https://scholarlyoa.com/ publishers/.

Berger, M. \& Cirasella, J. 2015. 'Beyond Beall's list: Better understanding predatory publishers', College \& Research Libraries News, 76(3): 132-135.

Bohannon, J. 2013. 'Who's afraid of peer review?', Science, 342: 6065 .

Butler, D. 2013. 'The dark side of publishing', Nature, 495: 433435 .

Department of Higher Education \& Training. 2014. Report on the evaluation of the 2013 universities' research outputs. [online] URL:http://www.justice.gov.za/commissions/FeesHET/docs/2015Report-Evaluation2013Universities.pdf.
Fiebert, S.M. 2014. 'A look at open access publication and Beall's list of "Predatory" Journals', Global Journal of interdisciplinary social sciences, 3(4): 5-6.

Harley, Y.X., Huysamen, E., Hlungwani, C. \& Douglas T. 2016. 'Does the DHET research output subsidy model penalise highcitation publication? A case study', South African Journal of Science, 112(5/6): 114-117.

McKerlich, R., Ives, C. \& McGreal, R. 2013. 'Measuring use and creation of open educational resources in higher education', International Review of Research in Open and Distance Learning, 14(4): 90-103.

Mouton, J. \& Valentine, A. 2017. 'The extent of South African authored articles in predatory journals', South African Journal of Science, 113(7/8): 79-87.

National Research Foundation, 2016. Guidelines on the completion of a rating reviewer report, unpublished.

Pyne, D. 2017. 'The rewards of predatory publications at a small business school', Journal of Scholarly Publishing. 48(3): 137-160.

Rahman, A.I.M., Guns, R. \& Engels, T.C.E. 2015. Predatory open access journals in a performance-based funding model: A comparison of journals in version VI of the VABB-SHW with Beall's list and DOAJ. Report submitted to the Gezaghebbende Panel, [online] https://www.google.com/url?sa=t\&rct=j\&q=\&esrc=s\& source $=$ web $\& c d=1 \& v e d=0$ ahUKEwjajdSRsr7PAhVLPCYKHfB 2 CAUQFggeMAA\&url=https $\% 3 \mathrm{~A} \% 2 \mathrm{~F} \% 2 \mathrm{Fwww}$. ecoom.be $\% 2 \mathrm{Fsite}$ s\%2Fecoom.be $\% 2$ Ffiles $\% 2 F d o w n l o a d s \% 2 F 151223$ Predatory $\% 25$ 20Journals\%2520VABB\%2520VI_incl_Annexes.pdf\&usg=AFQj CNFgh6AuW7B1UbpMioCHaE7vCWJyog\&sig2=s6W2NlvBKN R0zt2xvFn7Qw\&cad=rja.

Shen, C. \& Björk, B. 2015. "'Predatory” open access: A longitudinal study of article volumes and market characteristics', BMC Medicine, 2015(13): 230.

Sīle, L., Guns, R. \& Engels, T.C.E. 2017. Comparing VABB-SHW (version VII) with Beall's lists and DOAJ. Report submitted to the Gezaghebbende Panel [online]

URL:https://repository.uantwerpen.be/docman/irua/7df2a7/139654. pdf.

Silver, A. 2017. Pay-to-view blacklist of predatory journals set to launch. [online] URL:https://www.nature.com/news/pay-to-viewblacklist-of-predatory-journals-set-to-launch-1.22090

Solomon, D.J. \& Björk, B.C. 2012. 'A study of open access journals using article processing charges', Journal of the American Society for Information Science and Technology. 63(8): 1485-1495.

Stellenbosch University. 2016. [online] URL:http://www.sun.ac.za/ research/ research-outputs-and-accreditation/accreditedjournals.html.

Thomas, A. 2015. African academics are being caught in the predatory journal trap. The Conversation, 29 October 2015. [online] URL:https://theconversation.com/african-academics-are-beingcaught-in-the-predatory-journal-trap- 48473 .

Virtus InterPress. 2012a. Highlighting the corporate governance research communities: A case of the University of South Africa. [online] 
URL:http://www.virtusinterpress.org/IMG/pdf/University_of_Sout h_Africa.pdf.

Virtus InterPress. 2012b. Highlighting the corporate governance research communities: A case of Stellenbosch University. [online] URL:http://www.virtusinterpress.org/IMG/pdf/Stellenbosch_Unive rsity.pdf.

Wallace, F.H. \& Perri, T.J. 2016. Economists Behaving Badly: Publications in Predatory Journals. [online] URL:https://mpra.ub.uni-

muenchen.de/73075/1/MPRA_paper_73075.pdf.

Yu, D., Kasongo, A. \& Moses, M. 2016. 'Examining the performance of the South African economics departments, 20052014', South African Journal of Economics, 85(1): 138-158.

\section{Acknowledgements}

The authors gratefully acknowledge comments on previous drafts by Jeffrey Beall, Johann Mouton and Astrid Valentine. We also want to thank the National Research Foundation for their input.

\section{Appendix}

FIGURE 1: Journal choice flowchart that limits the risk of publishing in predatory journals

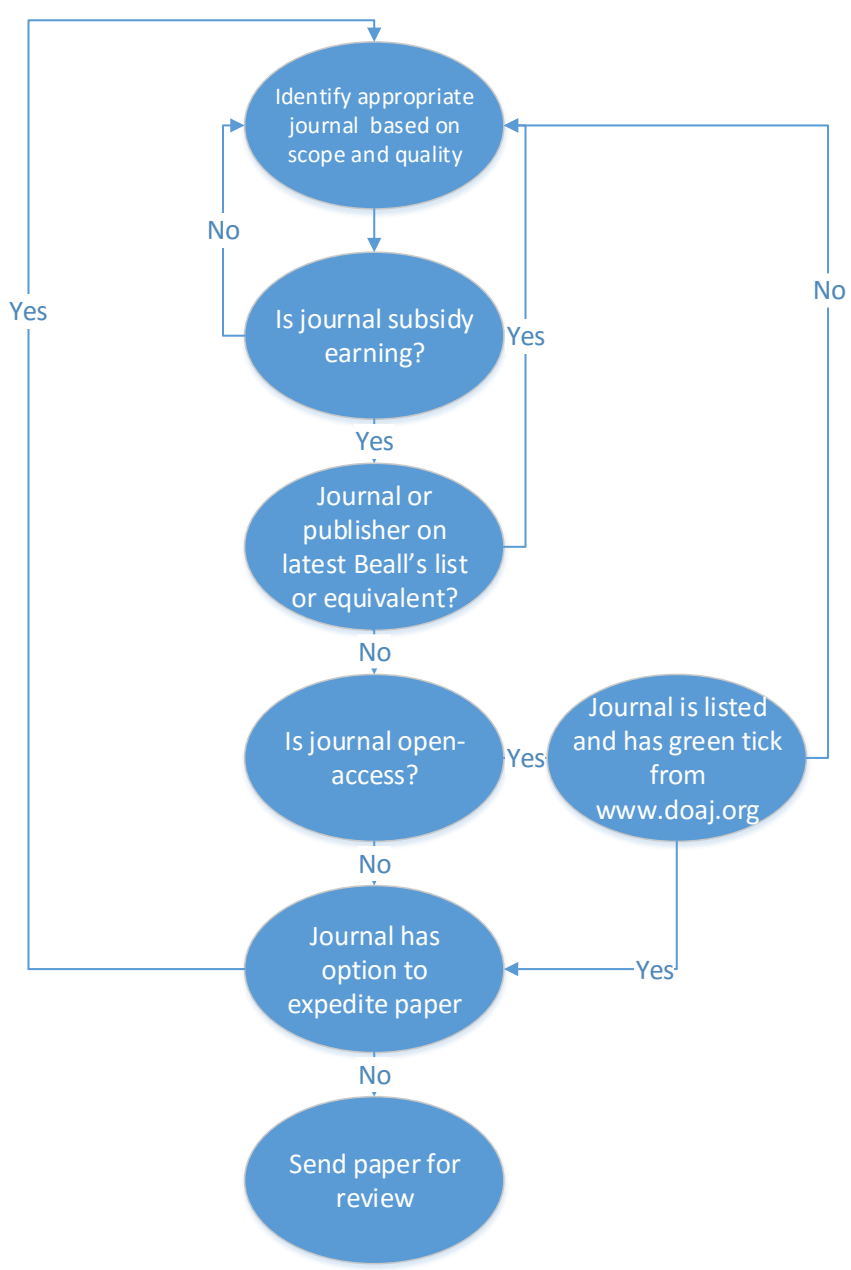

Alternatives to Beall's list are the journal blacklist by Cabell's International or in South Africa, potentially, a blacklist by CREST. 